\title{
Rate of Crystal Growth in $\mathrm{Li}_{2} \mathrm{O} \cdot 2 \mathrm{SiO}_{2}$ Glass
}

\author{
By \\ Kazumasa MATUSITA* and Megumi TASHIRO \\ (Institute for Chemical Research, Kyoto University)
}

\section{Introduction}

The $\mathrm{Li}_{2} \mathrm{O}-\mathrm{SiO}_{2}$ system is a base composition of typical commercial glass-ceramics and therefore its crystallization behaviors on re-heating have been studied extensively from various aspects ${ }^{12} \sim 15$. The present work is an addition to thus studies. The rates of crystal growth in $\mathrm{Na}_{2} \mathrm{O} \cdot 2 \mathrm{SiO}_{2}$ and $\mathrm{K}_{2} \mathrm{O} \cdot 2 \mathrm{SiO}_{2}$ glasses were already investigated by several workers ${ }^{16) \sim 19}$, while few reports have been published on the growth rate in $\mathrm{Li}_{2} \mathrm{O} \cdot 2 \mathrm{SiO}_{2}$ glass at temperatures near the melting temperature of the disilicate crystal. Very rapid crystallization of this glass ${ }^{20}$ made it difficult to measure the rate of crystal growth. In our previous works ${ }^{21), 22)}$ reporting the effects of added oxide on the crystallization of the $\mathrm{Li}_{2} \mathrm{O}-\mathrm{SiO}_{2}$ binary glass, it was shown that the rate of crystal growth was inversely proportional to the viscosity of glass. The temperature range where the growth rates were measured, however, was limited to $600^{\circ} \sim 700^{\circ} \mathrm{C}$, far below the melting temperature.

In the present study, a microfurnace in which the glass melt could be cooled to a given temperature very rapidly was constructed and attached to an ordinary polarizing microscope. Using this high temperature microscope, the rates of crystal growth in $\mathrm{Li}_{2} \mathrm{O} \cdot 2 \mathrm{SiO}_{2}$ glass with or without addition of a small quantity of alkali oxides other than lithia were measured. The measurements were made at temperatures ranging from $750^{\circ} \mathrm{C}$ to the melting point of lithium disilicate crystal, including the temperature of maximum crystal growth rate.

\section{Experimental Procedure}

\subsection{Preparation of glasses}

Glass compositions used were $\mathrm{Li}_{2} \mathrm{O} \cdot 2 \mathrm{SiO}_{2}$ and $33.3 \mathrm{Li}_{2} \mathrm{O} \cdot 66.7 \mathrm{SiO}_{2} \cdot 1.5 \mathrm{R}_{2} \mathrm{O}$ in mole $\left(\mathrm{R}_{2} \mathrm{O} ; \mathrm{Na}_{2} \mathrm{O}\right.$, $\left.\mathrm{K}_{2} \mathrm{O}, \mathrm{Cs}_{2} \mathrm{O}\right)$. Glasses were melted in the same way as reported in the previous study ${ }^{21}$.

\subsection{Measurement of the rate of crystal} growth

For the measurement of the rate of crystal growth a high temperature microscope set con-

* present address : Faculty of Engineering, Mie University
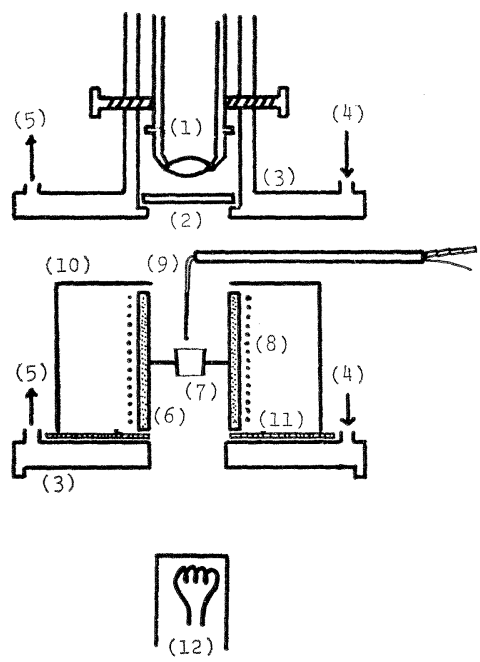

(1) objective lens of microscope (2) silica glass plate (3) water cooled casing (4) water inlet (5) water outlet (6) BeO cylinder ( 7 ) Pt crucible held with Pt wire (8) heating element ( $\mathrm{Pt}$ wire) (9) Pt $87 \mathrm{Pt} 13 \mathrm{Rh}$ thermocouple $(0.1 \mathrm{~mm} \phi)$ (10) stainless steel cylinder (11) mica (12) lamp

Fig. 1. Schematic representation of the high temperature microscope set.

sisting of an ordinary polarizing microscope and a microfurnace having a small heat capacity as schematically shown in Fig. 1 was constructed. The microfurnace consisted of a beryllium oxide cylinder, $6.15 \mathrm{~mm}$ in inside diameter, $8.85 \mathrm{~mm}$ in outer diameter and $17.4 \mathrm{~mm}$ in height. A platinum wire was wound around this cylinder as an heat element. A platinum crucible with a hole at the bottom, about $3 \mathrm{~mm}$ in diameter and about $2 \mathrm{~mm}$ deep, was held with a platinum wire at the center of the cylinder. The microfurnace was coverd with a stainless steel cylinder, $35 \mathrm{~mm}$ in diameter and $19 \mathrm{~mm}$ in height and a stainless steel plate having a hole of $8 \mathrm{~mm}$ in diameter in order to prevent the radiation loss and the effect of draught. The objective lens and the stage of the microscope were protected by water-cooled casings. Temperature was measured with a platinum-platinum $13 \%$ rhodium thermocouple of which diameter was $0.1 \mathrm{~mm}$. The thermocouple was attached to a micromanipulator so that it could move in 
three dimensions. Temperature gradient near the upper and lower ends in the beryllium oxide cylinder was relatively steep, but almost uniform near the center where the platinum crucible was held. The temperature difference in the crucible was within $\pm 2^{\circ} \mathrm{C}$ when the center of the crucible was kept at about $1000^{\circ} \mathrm{C}$. Heat capacity of the microfurnace was very small, and the temperature in the microfurnace could be changed very quickly ; for example, it fell from $1100^{\circ}$ to $750^{\circ} \mathrm{C}$ within 40 seconds.

The procedure of measuring the growth rate was as follows. Pieces of glass, $0.02 \sim 0.03 \mathrm{~g}$ were put into the platinum crucible and remelted at $1080^{\circ} \mathrm{C}$. The junction of the thermocouple was once immersed in the melt so that a small amount of melt adhered to it. The junction removed from the melt was then kept at a position within the furnace where the temperature was $900^{\circ} \mathrm{C}$ for about 5 minutes in order to crystallize the melt adhering on it. The furnace temperature was then lowered to a desired temperature, the thermocouple junction was immersed in the supercooled melt, and the crystals growing from the junction into the melt were photographed at intervals of $5 \sim 10$ seconds. The growth temperature indicated by the thermocouple rose due to the heat of crystallization by about 15 degrees in the maximum, and the mean of the temperatures at the start and the end of a measurement was taken as the growth temperature.

At lower temperatures, the insertion of the thermocouple junction into the melt was difficult because of high viscosity. Furthermore, the increased rate of surface nucleation interfered with the growth measurement. For these reasons, the measurement of the growth rate was almost impossible at the temperatures below $750^{\circ} \mathrm{C}$.

\subsection{Identification of precipitated crystals}

Identification of the precipitated crystals was made using the crystals grown from another melt because it was very difficult to remove the crystal from the top of the thermocouple without its damage. About $3 \mathrm{~g}$ glass was put into a hemispherical platinum crucible, $20 \mathrm{~mm}$ in diameter, which was hung in the furnace with a platinum wire, and remelted (Fig. 2). The tip of another platinum wire $(0.5 \mathrm{~mm} \phi)$ was immersed in the melt, pulled up and kept at the position of 900 ${ }^{\circ} \mathrm{C}$, in order to change the adhering melt into crystal. The platinum crucible was displaced to heat the melt at about $950^{\circ} \mathrm{C}$, and the wire tip to which the crystal adhered was again immersed in the melt. The crystal grew from the tip into the melt. When the crystal diameter reached about $1 \mathrm{~mm}$, the tip was removed from the melt and the adhering crystals were identified by

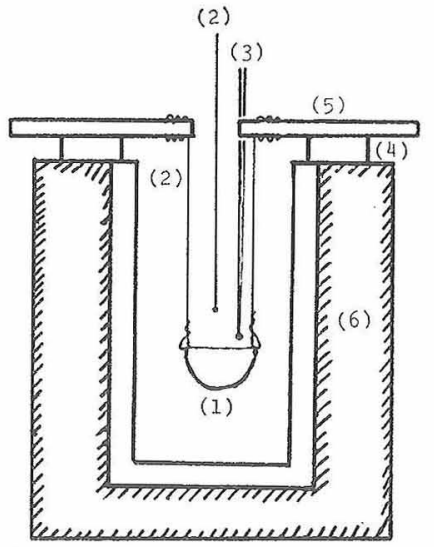

(1) $\mathrm{Pt}$ crucible (2) $\mathrm{Pt}$ wire (3) $\mathrm{Pt}-87 \mathrm{Pt} 13 \mathrm{Rh}$ thermocouple $(0.5 \mathrm{~mm} \phi)$ (4) refractory plate (5) alumina tube (6) vertical furnace with heat element of kanthal wire

Fig. 2. Vertical furnace used for preparing samples for identification of precipitated crystals.

$\mathrm{X}$-ray diffraction analysis.

\section{Experimentall Results}

\subsection{The rate of erystal growth}

The photograph of crystal growing in $\mathrm{Li}_{2} \mathrm{O}$. $2 \mathrm{SiO}_{2}$ glass is shown in Fig. 3 as an example.

(a)
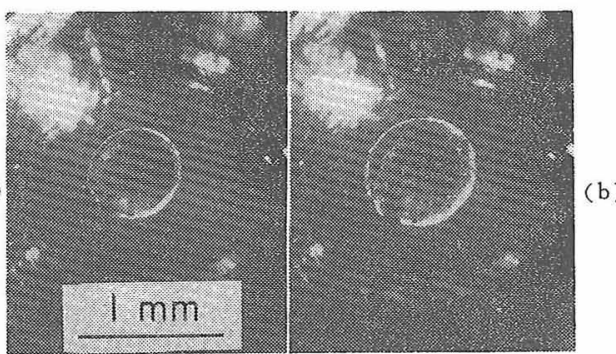

(c)

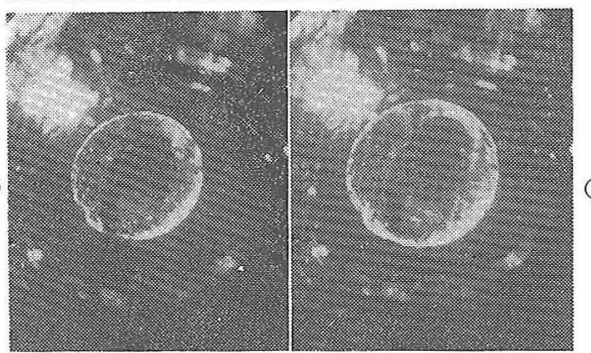

(d)

(e)

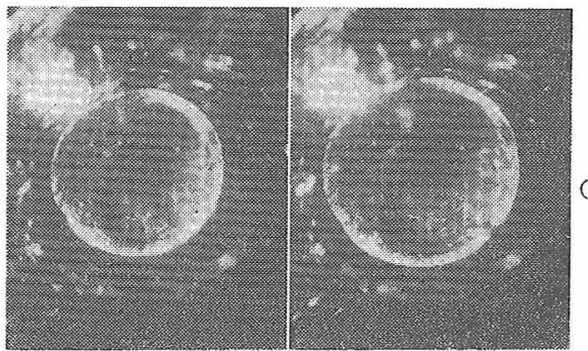

Fig. 3. Optical micrographs of crystals growing in $\mathrm{Li}_{2} \mathrm{O} \cdot 2 \mathrm{SiO}_{2}$ glass at $832^{\circ} \mathrm{C}$ taken at five seconds intervals. 


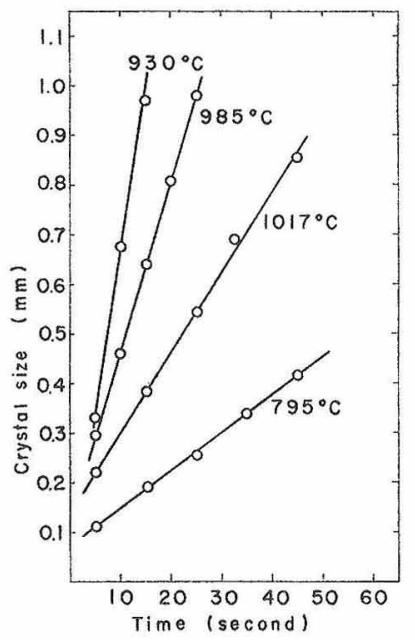

Fig. 4. Variation of crystal size with time.

(a)

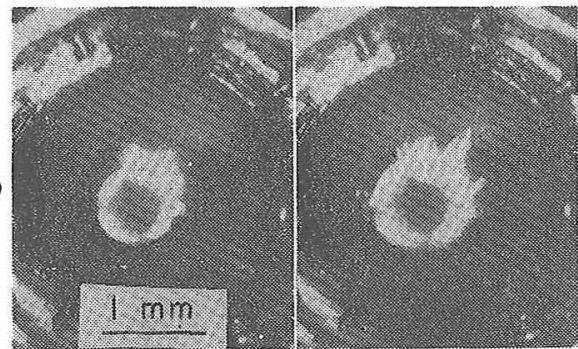

(b)

(c)

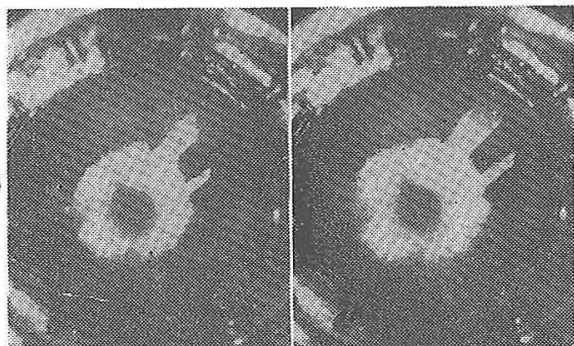

(d)

(e)

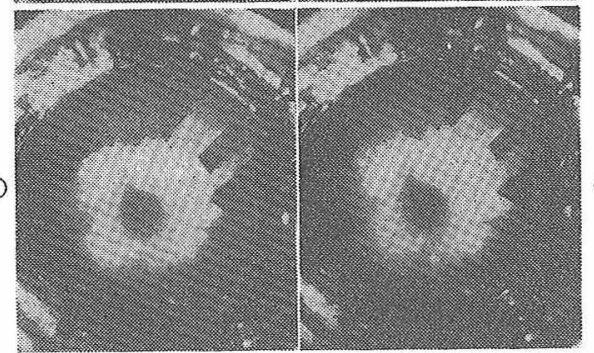

Fig. 6 Optical micrographs of crystals growing in $33.3 \mathrm{Li}_{2} \mathrm{O} \cdot 66.7 \mathrm{SiO}_{2} \cdot 1.5 \mathrm{Na}_{2} \mathrm{O}$ glass at $980^{\circ} \mathrm{C}$ taken at ten seconds intervals.

The radius of crystal particle was measured in such photographs. Variations of the radii with time at different temperatures are shown in Fig. 4 as examples. The slopes of these straight lines are the growth rates. The rates of crystal growth in $\mathrm{Li}_{2} \mathrm{O} \cdot 2 \mathrm{SiO}_{2}$ glass thus obtained are shown as a function of temperature in Fig. 5. The growth

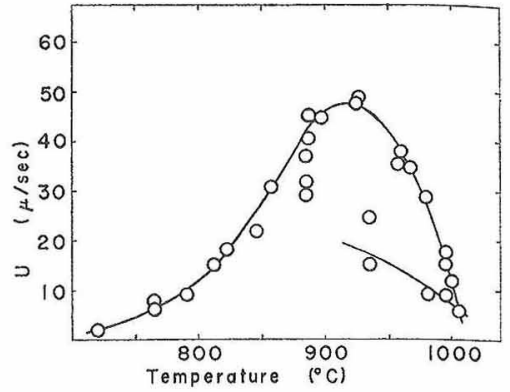

Fig. 7. Rate of crystal growth in $33.3 \mathrm{Li}_{2} \mathrm{O} \cdot 66.7 \mathrm{SiO}_{2} \cdot 1.5$ $\mathrm{Na}_{2} \mathrm{O}$ glass.

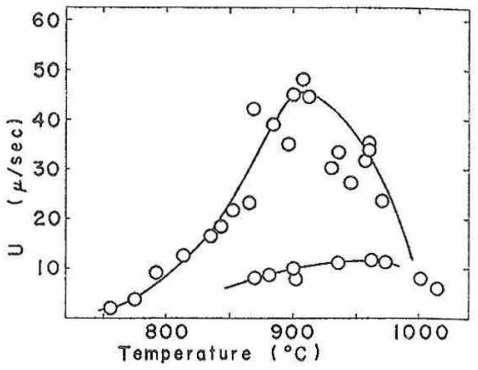

Fig. 8 Rate of crystal growth in $33.3 \mathrm{Li}_{2} \mathrm{O} \cdot 66.7 \mathrm{SiO}_{2} \cdot 1.5$ $\mathrm{K}_{2} \mathrm{O}$ glass.

rate reaches its maximum, $70 \mu / \mathrm{sec}$, at about 920 ${ }^{\circ} \mathrm{C}$, and becomes zero at $1033^{\circ} \mathrm{C}$. The latter temperature agrees with the liquidus temperature in the equilibrium phase diagrams given by $\mathrm{Kracek}^{23)}$. In glasses to which another alkali was added two kinds of crystals with different growth rates were precipitated simultaneously or separately. Fig. 6 shows photographs of the two crystals precipitated simultaneously. It is obvious that in such cases the growth rates of two kinds of crystals can be obtained simultaneously. The two kinds of growth rates in these glasses are shown in Fig. $7 \sim 9$.

\subsection{Identification of erystals}

Only lithium disilicate crystals $\left(\mathrm{Li}_{2} \mathrm{Si}_{2} \mathrm{O}_{5}\right)$ precipitated in $\mathrm{Li}_{2} \mathrm{O} \cdot 2 \mathrm{SiO}_{2}$ glass while the two kinds of crystals, lithium disilicate and lithium metasilicate $\left(\mathrm{Li}_{2} \mathrm{SiO}_{3}\right)$ crystals, precipitated in the glas-

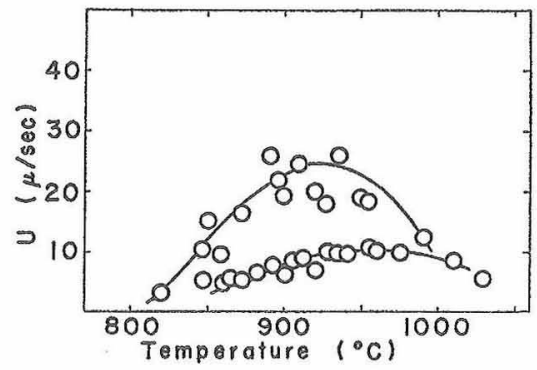

Fig. 9. Rate of crystal growth in $33.3 \mathrm{Li}_{2} \mathrm{O}$. $66.7 \mathrm{SiO}_{2} \cdot 1.5 \mathrm{Cs}_{2} \mathrm{O}$ glass. 
Table 1. The frequency of appearence of $\mathrm{Li}_{2} \mathrm{Si}_{2} \mathrm{O}_{5}$ and $\mathrm{Li}_{2} \mathrm{SiO}_{3}$ crystals in ten repeated experiments.

\begin{tabular}{|c|c|c|c|}
\hline $\begin{array}{r}\text { Crystal specie } \\
\text { Component added } \\
\end{array}$ & $\begin{array}{c}\text { Only } \\
\mathrm{Li}_{2} \mathrm{Si}_{2} \mathrm{O}_{5}\end{array}$ & $\begin{array}{l}\mathrm{Li}_{2} \mathrm{Si}_{2} \mathrm{O}_{5} \\
+ \\
\mathrm{Li}_{2} \mathrm{SiO}_{3}\end{array}$ & $\begin{array}{l}\text { Only } \\
\mathrm{Li}_{2} \mathrm{SiO}_{3}\end{array}$ \\
\hline None (Base glass) & 10 & 0 & 0 \\
\hline $\mathrm{Na}_{2} \mathrm{O}$ & 4 & 5 & 1 \\
\hline $\mathrm{K}_{2} \mathrm{O}$ & 0 & 3 & 7 \\
\hline $\mathrm{Cs}_{2} \mathrm{O}$ & 0 & 2 & 8 \\
\hline
\end{tabular}

ses with addition of another alkali oxide. Table 1 shows the crystalline species detected in ten repeated experiments.

\section{Discassion}

4.1 Mechanism of crystal growth in $\mathrm{Li}_{2} \mathrm{O}$.

\section{$2 \mathrm{SiO}_{2}$ glass}

The rate of crystal growth, $U$, is generally expressed by the formula ${ }^{24}$

$$
U=\frac{f D^{\prime \prime}}{a_{0}}\left[1-\exp \left(-\frac{\Delta G}{R T}\right)\right]
$$

where $f$ is the fraction of sites at the interface where molecules can preferentially be added, $D^{\prime \prime}$ is the diffusion coefficient for transport across the crystal-liquid interface, $a_{0}$ is the molecular diameter and $\Delta G$ is the free energy change per mole accompanying the transformation. If the Stokes-Einstein relation

$$
D^{\prime \prime}=\frac{R T}{3 \pi a_{0} N_{0} \eta}
$$

holds between the diffusion coefficient, $D^{\prime \prime}$, and the viscosity of glass, $\eta$, equation. (1) becomes

$$
U=\frac{f R T}{3 \pi a_{0}{ }^{2} N_{0} \eta}\left[1-\exp \left(-\frac{\Delta G}{R T}\right)\right]
$$

where $N_{0}$ is Avogadro's number.

Rewriting equation (3) in terms of a reduced growth rate, $U_{R}$, which is proportional to $f$

$$
U_{R}=\frac{U_{\eta}}{T[1-\exp (-\Delta G / R T)]}=\frac{f R}{3 \pi a_{0}{ }^{2} N_{0}}
$$

According to Jackson ${ }^{19)}$, materials with low entropy of fusion $\left(\Delta S_{f}<2 R\right)$ such as metals and $\mathrm{SiO}_{2}$, exhibit a continuous growth and the fraction, $f$, for such materials should be of the order of unity, not depending strongly on undercooling, $\triangle T$. On the other hand, materials with high entropies of fusion $\left(\Delta S_{f}>4 R\right)$ such as most silicates and organic compound show a lateral growth based on steps provided by screw dislocation and $f$ is proportional to $\Delta T$. This criterion suggests that $\mathrm{Li}_{2} \mathrm{Si}_{2} \mathrm{O}_{5}$, which has an entropy of fusion about $11 R$, should show lateral growth.

To confirm it, the relation between $U_{R}$ and $\Delta T$ is examined using equation (4). Estimate of the viscosities in the temperature range where the growth rates were measured was made from high temperature viscosities measured Shartsis et
("C)

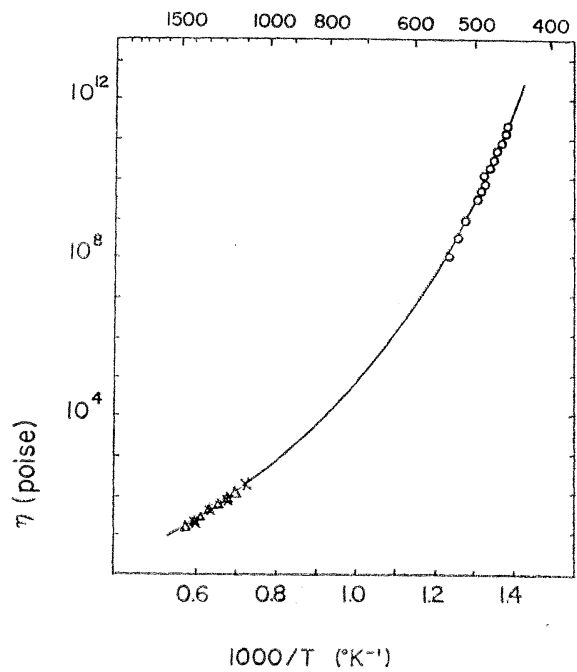

$\triangle$ L. Shartsis and S. Spinner ${ }^{25)}$

$\times$ J.O'M. Bockris, J.D. Mackenzie and J.A. Kitchner ${ }^{26)}$ K. Matusita and M. Tashiro ${ }^{20), 21)}$

Fig. 10. Viscosity of $\mathrm{Li}_{2} \mathrm{O} \cdot 2 \mathrm{SiO}_{2}$ glass estimated by using the Fulcher equation.

$\mathrm{al}^{25}$ and Bockris et $\mathrm{al}^{26)}$ and low temperature viscosities reported by the authors ${ }^{20), 21)}$ on the basis of the Fulcher equation

$$
\log \eta=A+\frac{B}{T-T_{0}}
$$

where $A, B$ and $T_{0}$ are constants. Determining these constants as for the Fulcher equation to express the measured viscosities, the following expression was obtained

$$
\log \eta=-1.44+\frac{3.37 \times 10^{3}}{T-460}
$$

The relation between $\eta$ and $1 / T$ estimated from this equation is shown in Fig. 10. The free energy difference, $\Delta G$, between crystal and glass

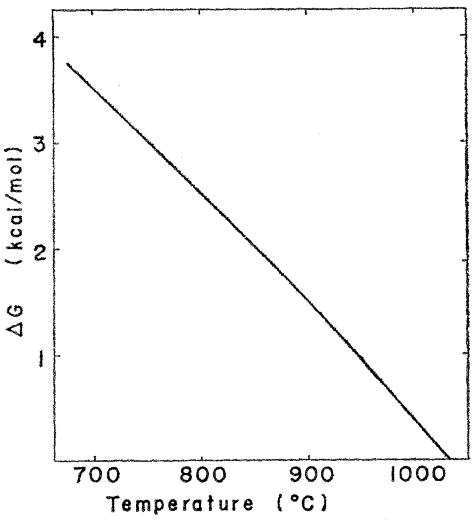

Fig. 11. Free energy difference between crystal and glass for $\mathrm{Li}_{2} \mathrm{O} \cdot 2$ $\mathrm{SiO}_{2}$ system (after Takahashi and Yoshio $^{27)}$ ). 


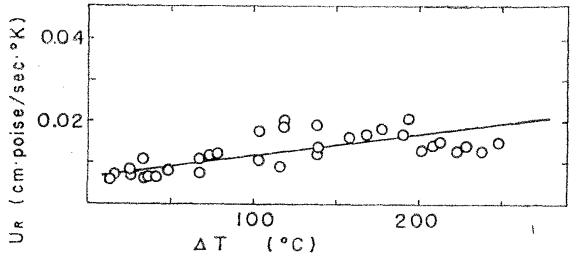

Fig. 12. Reduced growth rate, $U_{R}=U \eta$ $T[1-\exp (-\Delta G / R T)]$, in $\mathrm{Li}_{2} \mathrm{O}$. $2 \mathrm{SiO}_{2}$ glass as a function of undercooling.

was obtained experimentally by Takahashi and Yoshio $^{27)}$. The relation between the $\Delta G$ and the temperature is shown by the solid line in Fig. 11. Using the values of $\eta, \Delta G$ and $U$ (Fig. 5), $U_{R}$ was calculated as a function of $\Delta T$ which is shown in Fig. 12. It can be seen that, although the data scatter to some extent, $U_{R}$ can be expressed by a linear function of $\Delta T$ with a positive slope. This is compatible with the concept that the $\mathrm{Li}_{2} \mathrm{Si}_{2} \mathrm{O}_{5}$ crystal grows by the screw dislocation mechanism. The slope of the line obtained by the least square method was $(4.02 \pm 0.53) \times$ $10^{-5} \mathrm{~cm}$ poise $/ \mathrm{sec}(\mathrm{deg})^{2}$.

The theory of growth by screw dislocation mechanism ${ }^{28)}$ tells that $f$ is expressed by

$$
f=\frac{3 a_{0} \Delta H_{f} \Delta T}{4 \pi \sigma T_{m} V}
$$

where $\Delta H_{f}$ is the enthalpy of fusion at the melting point, $T_{m}, \sigma$ is the crystal-glass interfacial energy, and $V$ is the molar volume of the crystal. Substituting equation (6) into equation (4) and using the values ${ }^{20)}, \Delta H_{f}=14.6 \mathrm{kcal} / \mathrm{mole}, V=61$ $\mathrm{cm}^{3} / \mathrm{mole}, \sigma=196 \mathrm{erg} / \mathrm{cm}^{2}$ and the assumption $a_{0}=$ $3 \AA$, the slope of the straight line representing the relation between $U_{R}$ and $\Delta T$ was calculated to be about $5 \times 10^{-6} \mathrm{~cm}$ poise $/ \mathrm{sec}(\mathrm{deg})^{2}$, which is about $1 / 8$ of the experimentally obtained value. This discrepancy may be attributed to $a_{0}$-value arbitrarily taken and to the fact that the Stokes Einstein relation of equation (2) is not strictly correct. It was suggested that $D^{\prime \prime}$ is larger $10 \sim$ 100 times than $D$, the diffusion coefficients in bulk liquid ${ }^{29}$. Also Meiling et al $^{17)}$ reported that $D^{\prime \prime}$ was larger 150 times than the value estimated from the Stokes-Einstein relation for $\mathrm{Na}_{2} \mathrm{O} \cdot 2 \mathrm{SiO}_{2}$ glass.

\subsection{Relation between $D^{\prime \prime}$ and $\eta$}

There are some arguments ${ }^{29) \sim 31)}$ on the validity of the Stokes-Einstein relation between $D^{\prime \prime}$ and $\eta$, and, as previously noted, experimentally obtain. ed $D^{\prime \prime}$ is not necessarily equal to that estimated from the equation (2). It was often shown, however, that the activation energy for diffusion at the crystal-melt interface is equal to that for viscous flow of the melt; both energies were equal in the growth of cristobalite ${ }^{31)}$ and in the

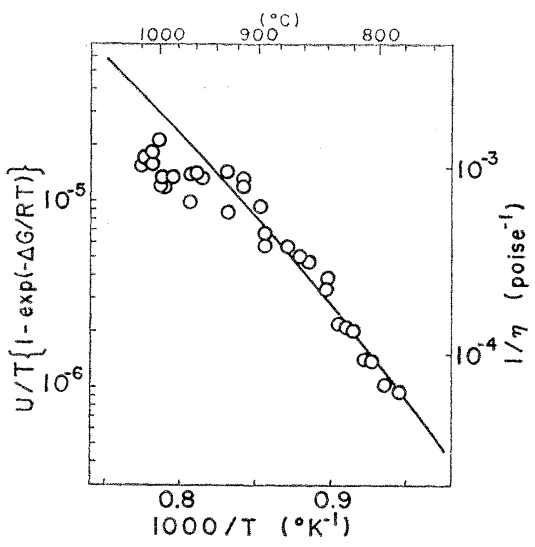

Fig. 13. Reduced growth rate, $U / T[1-\exp$ $(-\Delta G / \mathrm{RT})]$, in $\mathrm{Li}_{2} \mathrm{O} \cdot 2 \mathrm{SiO}_{2}$ glass (open circles) and the reciprocal of the viscosity of this glass (solid line).

crystal growth in $\mathrm{Na}_{2} \mathrm{O} \cdot 2 \mathrm{SiO}_{2}$ glass ${ }^{17)}$. These facts suggest that the dependence of the both sides of equation (2). on temperature is equal, that is to say, at least the relation

$$
D^{\prime \prime} \propto T / \eta
$$

holds between $D^{\prime \prime}$ and $\eta$. Then, combining equation (7) and (1),

$$
\frac{U}{T[1-\exp (-\Delta G / R T)]} \propto \frac{1}{\eta}
$$

$f$ was regarded as constant because its temperature dependence is very weak as compared with that of $\eta$.

The plot of $U / T[1-\exp (-\Delta G / R T)]$ against $1 / T$ is shown by open circles in Fig. 13. The solid line in this figure represents the $1 / \eta \sim 1 / T$ plot obtained from equation (5). Except the temperature region near the melting point, $U / T$ $[1-\exp (-\Delta G / R T)]$ agrees closely with $1 / \eta$, indicating that the equation (7) holds. In other words, the activation energy for diffusion across the crystal-melt interface is equal to that for viscous flow of the melt.

\subsection{Effect of the addition of alkali oxides}

It is seen from Table 1 that the addition of an alkali oxide other than $\mathrm{Li}_{2} \mathrm{O}$ induces the precipitation of $\mathrm{Li}_{2} \mathrm{SiO}_{3}$ crystal and that the proportion of $\mathrm{Li}_{2} \mathrm{SiO}_{3}$ crystal to the total amount of precipitated crystals increases in the order of $\mathrm{Na}_{2} \mathrm{O}<$ $\mathrm{K}_{2} \mathrm{O}<\mathrm{Cs}_{2} \mathrm{O}$.

In the equilibrium phase diagrams of $\mathrm{SiO}_{2}-\mathrm{Li}_{2} \mathrm{O}$ $-\mathrm{R}_{2} \mathrm{O}(\mathrm{R} ; \mathrm{Na}, \mathrm{K})^{32)}$, the temperature range in which only $\mathrm{Li}_{2} \mathrm{SiO}_{3}$ crystal exists stably as primary phase broadens and the amount of $\mathrm{Li}_{2} \mathrm{SiO}_{3}$ crystals in the end product increases as another alkali oxide is added to $\mathrm{Li}_{2} \mathrm{O} \cdot 2 \mathrm{SiO}_{2}$ composition. This temperature range is broader and the proportion of $\mathrm{Li}_{2} \mathrm{SiO}_{3}$ to the total amount of end pro- 
ducts is larger in the system containing $\mathrm{K}_{2} \mathrm{O}$ than in the system containing $\mathrm{Na}_{2} \mathrm{O}$. These facts explain the present results. The equilibrium phase diagram of the system containing $\mathrm{Cs}_{2} \mathrm{O}$ is not reported yet, but it would be reasonable to expect that the temperature range would broaden further and the proportion would be larger.

It was seen in Fig. $7 \sim 9$ that the frequency of appearance of the crystal growing with. lower growth rate increases in the order of $\mathrm{Na}_{2} \mathrm{O}<\mathrm{K}_{2} \mathrm{O}$ $<\mathrm{Cs}_{2} \mathrm{O}$. Combining this with the above facts the crystal with lower growth rate can be assigned to $\mathrm{Li}_{2} \mathrm{SiO}_{3}$ crystal.

\section{Summary}

1. The rates of crystal growth in $\mathrm{Li}_{2} \mathrm{O} \cdot 2 \mathrm{SiO}_{2}$ and $33.3 \mathrm{Li}_{2} \mathrm{O} \cdot 66.7 \mathrm{SiO}_{2} \cdot 1.5 \mathrm{R}_{2} \mathrm{O}$ glasses (mole ratio) were measured under a high temperature microscope equipped with a microfurnace having a very small heat capacity.

2. The growth rate of $\mathrm{Li}_{2} \mathrm{Si}_{2} \mathrm{O}_{5}$ crystal precipitating in $\mathrm{Li}_{2} \mathrm{O} \cdot 2 \mathrm{SiO}_{2}$ glass reached maximum $(70 \mu / \mathrm{sec})$ at about $920^{\circ} \mathrm{C}$. The analysis of growth rates based on the theory of crystal growth indicated the screw dislocation mechanism.

3. A relation $D^{\prime \prime} \propto T / \eta$ predicted from the Stokes-Einstein relation was found between the diffusion coefficient across the crystal-melt interface, $D^{\prime \prime}$, which was obtained from growth rate, and the viscosity of the melt, $\eta$. In other words the activation energy for diffusion across the crystal-melt interface was equal to that for viscous flow of the melt.

4. In the glasses with addition of another alkali oxide $\mathrm{Li}_{2} \mathrm{SiO}_{3}$ crystal precipitated besides $\mathrm{Li}_{2} \mathrm{Si}_{2} \mathrm{O}_{5}$ crystal in accord with the pertinent phase diagrams. The proportion of $\mathrm{Li}_{2} \mathrm{SiO}_{3}$ to the total amount of the precipitated crystals increased in the order $\mathrm{Na}_{2} \mathrm{O}<\mathrm{K}_{2} \mathrm{O}<\mathrm{Cs}_{2} \mathrm{O}$.

\section{Acknowledgement}

The authors wish to thank Professor Sumio Sakka of Mie University who kindly gave fruitful suggestions and examined the manuscript carefully. Also thanks go to Professor Katsuaki Takahashi and Mr. Tetsuo Yoshio of Okayama University for allowing us to see free energy data prior to publication.

\section{References}

1) M. Tashiro, "Proceeding of Eighth International Congress" London (1968) p. 113-22.

2) M. Ito, T. Sakaino and T. Moriya, Bull. Tokyo Inst. Technol., [88] 127 (1968).

3) W.Vogel, Glass Technol. 7, 15 (1966).
4) J.G. Morley, ibid 6, 77 (1965).

5) K. Nakagawa and T. Izumitani, Phys. Chem. Glasses 10, 179 (1969).

6) V.I. Aveŕyanov and E.A. Porai-Koshits, "The Structure of Glass" vol. 5, Consultants Bureau, New York (1965) p. 63.

7) F.P. Glasser, Phys. Chem. Glasses 8, 224 (1967).

8) A.R. West and F.P. Glasser, Mat. Res. Bull. 5, 837 (1970).

9) R.J. Charles, J. Am. Ceram. Soc. 46, 235 (1963).

10) S.V. Phillips and P.W. McMillan, Glass Technol. 6, 46 (1965).

11) S.W. Freiman and L.L. Hench, J. Am. Ceram. Soc. 51, 382 (1968).

12) D.L. Kinser and L.L. Hench, ibid. 51, 445 (1968).

13) L.L. Hench, S.W. Freiman and D.L. Kinser, Phys. Chem. Glasses 12, 58 (1971).

14) S.W. Freiman and L.L. Hench, J. Am. Ceram. Soc. 55, 86 (1972).

15) R.H. Doremus and A.M. Turkalo, Phys. Chem. Glasses 13, 14 (1972).

16) W.D. Scott and J.A. Pask, J.Am. Ceram. Soc. 44, 181 (1961).

17) G.S. Meiling and D.R. Uhlman, Phys. Chem. Glasses 8, 62 (1967).

18) A. Leontiewa, Acta Physicochem. USSR 16, 97 (1964).

19) K.A. Jackson, D.R. Uhlmann and J.D. Hunt, $J$. Crystal Growth 1, 1 (1967).

20) K. Matusita and M. Tashiro, J. Non-Crystalline Solids 11, 471 (1973).

21) K. Matusita and M. Tashiro, Phys. Chem. Glasses 14, [4] (1973).

22) K. Matusita, T. Maki and M. Tashiro, Phys. Chem. Glasses, to be published.

23) F.C. Kracek, J. Phys. Chem. 34, part II, 2645 (1930).

24) D. Turnbull and M.H. Cohen, "Modern Aspects of the Vitreous State", vol. 1, Butterworths, New York (1960) p. 35-62.

25) L. Shartsis, S. Spinner and W. Capps, J. Am. Ceram. Soc. 35, 155 (1952).

26) J.O'M. Bockris, J.D. Mackenzie and J.A. Kitchener, Trans. Far. Soc. 55, 1734 (1955).

27) K. Takahashi and T. Yoshio, Yogyo-Kyokai-Shi, to be published.

28) W.B. Hillig and D. Turnbull, J. Chem. Phys. 24, 914 (1956).

29) J.W. Cahn, W.B. Hillig and G.W. Sears, Acta Met. 12, 1421 (1964).

30) H. Rawson, "Inorganic Glass-forming System" Academic Press, London and New York (1967) p. 78-83.

31) F.E. Wagstaff, J. Am. Ceram. Soc. 52, 650 (1969)

32) "Phase Diagrams for Ceramists", ed. E.M. Levin, C.R. Robbines and H.F. Murdie, Fig. 430 and Fig. 377, American Ceramic Society (1964).

[Received December 21, 1972] 


\title{
$\mathrm{Li}_{2} \mathrm{O} \cdot 2 \mathrm{SiO}_{2}$ ガラス中における結晶成長速度
}

\author{
松下和 正*田 代 仁 \\ （宗都大学 化学研究所)
}

熱容量が非常に小さい小型の加熱炉索つくり，これ老 通常の偏光顕微鏡に取りつけた。この高温顕微鏡を用い て, $\mathrm{Li}_{2} \mathrm{O} \cdot 2 \mathrm{SiO}_{2}$ および $33.3 \mathrm{Li}_{2} \mathrm{O} \cdot 66.7 \mathrm{SiO}_{2} \cdot 1.5 \mathrm{R}_{2} \mathrm{O}$ ( R; $\mathrm{Na}, \mathrm{K}, \mathrm{Cs}$ ) ガラス中に析出する結晶の成長速隻学 測定した. $\mathrm{Li}_{2} \mathrm{O} \cdot 2 \mathrm{SiO}_{2}$ ガラス中には,リチウム・2 珪 酸塩結晶のみが析出した。成長速度の測定值および結晶

*現在 三重大学 工学部
成造理諭より，この結晶は螦旋転位機棈によって成主与 ることが推察された。また, 結晶一融液界涌に扔ける我 散の活性化エネルギ一は，融液の粘性の活性化エネルギ 一に等しいことを確めた. $33.3 \mathrm{Li}_{2} \mathrm{O} \cdot 66.7, \mathrm{SiO}_{2} \cdot 1.5 \mathrm{R}_{2} \mathrm{O}$ ガラスからは, リチウム・ 2 珪酸塩結晶とともにリチウ ム・メ夕珪酸程結晶女析出した。

$(12 / 21 / 1972$ 受村) 